gon, and Japan have the same indicated value. The Japanese form which was supplied as Digitalis sp. proved upon flowering, to be one of the purest forms of Digitalis purpurea under investigation.

In this respect there is much uncertainty as to the nomenclature of the purpurea group and many of the varieties now recorded will doubtless be reduced to synonymy. Many of these varieties consist of a conglomeration of types which must be isolated and cultivated as pure strains before they will possess further value for experimental purposes.

The narrow leafed forms, represented by such species as canariensis ambigua, lutea, and lanata have been found true to name and reproduce themselves in pure stand. Synonymy also exists in this group but the classification will be easier than in the broad leafed forms. A thorough systematic investigation of the whole genus will be necessary before further work can be done upon the comparative medicinal value of the various species and varieties.

In conclusion it may be pointed out that accurate botanical investigations should precede or accompany any comparative investigations of this group of plants; that the results indicate that good digitalis leaf may be obtained from the first year flowerless plants; that cultivation in itself does not lessen toxicity and, that valuable forms other than purpurea may be found among the many species and horticultural varieties not hitherto investigated.

(1) Paschkis: Apoth. Ztg., 1888, 869.

(8) Gaschkis: Apoth. Ztg-, 1888, 869.

LITERATURE CITED.

(8) Boudgest: Pharm. Ztg., 1908, 18, No, 92, from Nouv. Remed., 1903, Nn. 21.

Departments of Botany and Experimental Medicine. Eli Lilly \& ComPANY, Indianapolis, August, 4th, 1913.

\title{
INFLUENCE OF HEAT AND METHOD OF STORING UPON THE POTENCY OF DIGITALIS LEAVES.
}

CHAS. C. HASKELL AND F. A. MILLER.

Two points of much interest to the pharmacist and to the physician are the most desirable methods of curing and preserving digitalis leaves.

It is important to know whether the use of a moderately high degree of temperature is permissible, because, if such be the case, rapid drying can be accomplished and the theoretical, injurious enzyme destroyed and dependence upon favorable atmospheric conditions can thus be obviated.

$\mathrm{Hart}^{3}$ finds that subjecting the leaves to an "excessive temperature" caused a loss in activity of 25 percent. Unfortunately, he does not state what this temperature was. $\mathrm{Hale}^{2}$, using dried leaves (moisture content of about 10 percent), concluded that the strength of the leaves, as determined by Cushny's method, is unaffected by a temperature up to $120^{\circ} \mathrm{C}$., but that a temperature of $140^{\circ} \mathrm{C}$. for two hours has an injurious action.

Our experiments were carried out upon leaves from conservatory grown plants of Digitalis gloxinizflora. These plants were eight months old when tested, and in some instances a sufficient supply of leaves was secured from each plant to 
enable us to carry out all comparative tests on a single plant, thus eliminating the possibility of variation due to individual plant differences.

The leaves, after drying were reduced to No. 60 powder and tinctures were made, using 75 percent alcohol as a menstruum. These tinctures were tested by Cushny's frog method and in a few cases the lethal dose for guinea pigs also was determined. In testing upon guinea pigs, the alcohol was not removed.

\section{EXPERIMENT I.}

No.

B-1115

B-1116

B-1117

No.

B-1124

B-1128
Digitalis Gloxiniaeflora, Single Plant.

Dried at Frog Assay.

$120^{\circ}$ C. 4 hours

$50^{\circ}$ C. 24 hours

$35^{\circ} \mathrm{C} .5$ days

$40^{\circ}$ C. 3 hours

EXPERIMENT II.

Digitalis Gloxiniaeflora, Single Plant.

Dried at

$120^{\circ}$ C. 12 hours

$80^{\circ} \mathrm{C} .5$ hours
0.0055

0.0055

0.0050

Frog Assay.

0.0065

0.0065
Guinea Pig Assay.

0.0020 .0025

0.0030

0.025

The frog heart assays of these samples give values near those secured with similar samples of Digitalis purpurea. The extremely high toxicity for guinea pigs is explainable by the menstruum used. It has been our experience that an alcoholic menstruum of 75 percent enables the percolation of a tincture much more toxic for guinea pigs but not much stronger on frogs than one made with 50 percent alcohol.

From these experiments, it seems safe to conclude that a temperature of $120^{\circ}$ C. applied to green leaves causes no greater loss in toxicity or ability to influence the frog's heart than does a temperature of $40^{\circ} \mathrm{C}$.

There is apparently little agreement as to the keeping qualities of dried digitalis leaves exposed to the air. Focke ${ }^{2}$ claims that one month is sufficient time for a considerable loss in strength to occur when the leaves are exposed to the air and contain more than 1.5 percent moisture. Pratt ${ }^{5}$ reaches somewhat similar conclusions. $\mathrm{Hale}^{2}$ on the contrary, finds that leaves containing from 5.8 to 9.4 percent moisture are very active at the expiration of one, two, three and eight years, respectively. Hatcher and Eggleston*, also, have been unable to see that digitalis leaves from three to five years old are any less potent than fresh samples.

Our own experiments bearing on this point have extended over only one year, but it seems that the additional evidence they present justifies their being reported.

The remainder of sample B-1124, which had been dried at $120^{\circ} \mathrm{C}$. for twelve hours and gave a frog value of 0.0065 was divided into two portions, B-1129 and B-1130. These two portions were placed in wide-mouthed amber bottles, one being carefully stoppered and sealed with paraffin, while the other was closed with a loosely-fitting plug of absorbent cotton.

EXPERIMENT III.

Digitalis Gloxiniaefora, Single Plant.

$\begin{array}{ccccc} & & & \text { Assay 12 Months } \\ \text { No. } & \text { Method of Storage. } & \text { Original Assay. } & \text { Later. } & \text { Moisture. } \\ \text { B-1129 } & \text { Open Bottle } & 0.0065 & 0.006 & 5.43 \\ \text { B-1130 } & \text { Sealed Bottle } & 0.0065 & 0.006 & 2.31\end{array}$


The remainder of sample B-1128, dried at $80^{\circ} \mathrm{C}$. for five hours, which originally tested 0.0065 , was divided into two portions, B-1131 and B-1132, and stored in a manner similar to that described above.

EXPERIMENT IV.

Digitalis Gloxiniaeflora, Single Plant.

$\begin{array}{ccccc} & & 3 & \text { Assay } 12 \text { Months } \\ \text { No. } & \text { Manner of Storage. } & \text { Original Assay. } & \text { Later. } & \text { Moisture Content. } \\ \text { B-1131 } & \text { Open Bottle } & 0.0065 & 0.0055 & 6.04 \\ \text { B-1132 } & \text { Sealed Bottle } & \mathbf{0 . 0 0 6 5} & 0.0060 & 2.83\end{array}$

A third sample was secured by collecting leaves from several different plants of Digitalis gloxiniæflora. These leaves were dried at $30^{\circ}$ to $55^{\circ} \mathrm{C}$. for twenty hours; reduced to a No. 60 powder and gave a value of 0.006 . Two lots were stored as in the preceding experiments.

\section{EXPERIMENT V.}

Digitalis Gloxiniaeflora, Several Plants.

\begin{tabular}{ccccc} 
& & \multicolumn{3}{c}{ Assay 12 Months } \\
No. & Nanner of Storagc. & Original Assay. & Later. & Moisture Content. \\
B-1134 & Open Bottle & 0.006 & 0.006 & $\mathbf{5 . 9 2}$ \\
B-1133 & Sealed Bottle & 0.006 & 0.006 & 4.76
\end{tabular}

From these experiments, it is safe to conclude that in one year no deterioration occurred in our samples of leaf, irrespective of the manner of storage, even when the moisture content was as great as 6.04 percent.

In some instances, a higher value is secured on the second assay than was obtained on the fresh leaf. This is to be explained by the limits of experimental error inherent in the assay method, as in all except one case, this difference does not amount to 10 percent.

$$
\text { DIGITALIS LEAF. }
$$

1. Focke: Arch. d. Pharm., 1903, Vol. 241, p. 128

1. Hale: Bull. No. 74, Hyg. Lab., U. S. P. H. and M. H. S

3. Hart: Pharm. Jour. Voi. 26 . p. 440

4. Hatcher and Eggleston: Druggists' Circular, Vol. LVII, 1913, No. 6, p. 325.

5. Pratt: Bos. Med, and Surg. Jour., Vol. 163, p. $279,1910$.

Departments of Experimental. Medicine and Botany, Eli Lilly \& Co., Indianapolis, Ind.

\section{INFLUENCE OF SOIL COMPOSITION ON MEDICINAL PLANTS.}

\section{F. A. MILlER, M. S.}

Observations upon the influence of soil composition on medicinal plants have been made by several investigators. These observations have indicated that certain variations may occur in the percentage of active principles when the growing plants are subject to different soil conditions. Agriculturists have long recognized the influence of soil composition upon crop production. Their methods of measuring this influence, however, have differed from those employed with medicinal plants. Results have usually been determined by amount of total crop produced and not by chemical and biological assay. Recently some work has been done upon the chemical determination of certain constituents such as oil, 